\title{
TOXICITY AND REPELLENCY EFFECTS OF FIVE ESSENTIAL OILS AGAINST TETRANYCHUS URTICAE KOCH, AND THE PREDATORY MITE AGISTEMUS EXSERTUS GONZALEZ (ACARI: TETRANYCHIDAE, STIGMAEIDAE)
}

\author{
Eman H.M. Walash \\ Plant Protection Research Institute, Dokki, Giza, Egypt
}

Received: Apr. 1, 2018

Accepted: Apr. 29,2018

\begin{abstract}
The present study was carried out to conduct a laboratory test of toxicity, and repellency or attractancy effects of five essential oils (garlic, thyme, menthol, jojoba and camphor) against Tetranychus urticae and Agistemus exsertus. Results indicated that garlic oil gave the highest percentages of mortality when used at $2 \%$ concentration (81.43\%) as mean mortality after 7 days of spray on the two spotted spider mite, $T$. urticae followed by camphor, recorded $27.14,42.86$ and $65.00 \%$ mean mortality at $0.5,1.0$ and $2.0 \%$ concentrations, while jojoba oil recorded only $32.14 \%$ mean mortality ranged from 6.43 to $79.29 \%$ when concentrations from 0.5 to $10 \%$ used. The lowest effect was obtained when menthol oil was used, only $14.29 \%$ mean mortality obtained at $2.0 \%$ concentration while the highest mortality obtained at $10.0 \%$ concentration $(77.86 \%$ after 7 days). As for the predatory mite, A. exsertus, data cleared that both garlic and camphor have high toxic effect when $5.0 \%$ and $10.0 \%$ concentrations used, recorded $66.43,79.29 \%$ for garlic and $62.14,77.14 \%$ for camphor. While thyme gave the lowest effect followed by jojoba with $10.0 \%$ concentration. The most safety oil on the predatory mite was menthol, without any effect at $0.5,1.0,2.0 \%$ concentration. Also, the study showed that menthol and camphor have high repellency effect after one and six hours, but the thyme oil have the lowest repellency effect where recorded the second class of repellency (21:40\%) after one hour for $T$. urticae. The obtained results also indicated that the camphor oil have the highest repellency oil, $2.0 \%$ concentration for the predator mite $A$. exsertus. It could be concluded that both garlic and camphor are sufficient oils to control of $T$. urticae at $10.0 \%$ concentration and more toxic on A. exsertus, Also menthol have high repellency effect and good toxicity effect on T. urticae with safe use on A. exsertus also thyme have sufficient toxicity effect on T. urticae.
\end{abstract}

Key words: Toxicity, repellency, Essential oils, Tetranychus urticae, Agistemus exsertus.

\section{INTRODUCTION}

Among the different species of mites of the family Tetranychidae, the twospotted spider mite (Tetranychus urticae) is considered the most important. This cosmopolitan pest feeds on several plant species, including fruits, vegetables and ornamental plants worldwide (Johnson and Lyon, 1991). About 1,200 plant species of which more than 150 are economically important have been reported as the mite's host (Zhang et al.,
2003; Jeppson et al., 1975). The main form of control for $T$. urticae is the use of synthetic pesticides, together with biological control involving the predatory mite Agistemus exsertus Gonzalez, which is a natural predator of $T$. urticae found on different crops worldwide. Predacious mites in the family Stigmaeidae are important natural enemies of several phytophagous mite pests on various crops (Hoyt, 1969; Gomaa, 1975; Santos, 1976). A. exsertus 
was reported as the most abundant stigmaeid species $(85 \%)$ in a number of Egyptian cropping systems (Zaher, et al. 1971; Solimon, et al. 1976). This stigmaeid mite has been reported as an egg predator of tetranychid mites ( $T$. urticae) (EL-Badry, et al. 1969; Oomen 1982; Hafez et al. 1983; EL-Bagoury et al. 1989; Yue and Childers, 1994). However, the continual use of conventional acaricides has caused serious damage due to environmental contamination as well as the elimination of predacious mites and various pollinating insects, so to reduce these negative effects, alternative methods for the control of $T$. urticae are being tested, including the use of essential oils (Motazedian et al., 2012). Essential oils are promising agents for the control of agricultural pests, as these substances act on the nervous system of the target insect, causing physiological and behavioral responses (Mossi et al., 2013). Essential oils extracted from aromatic plants have been widely investigated because they are deemed as potentially becoming the alternative to replace synthetic pesticides and because of also being more convenient to use. Generally, essential oils are mostly non toxic to mammals, birds and fish (Isman, 2006). On the other hand, they act as broad spectrum pesticides, that may affect pests, their natural enemies and pollinators due to their several modes of action including repellency and antifeedant activity, disruption of molting and cuticle, as well as retardation of growth and fecundity (Cosimi et al., 2009; Sertkaya et al., 2010).

The aim of the present study was to conduct a laboratory test of toxicity, repellency and attractancy effects of five essential oils (Garlic, Thyme, Menthol, Jojoba and Camphor) against $T$. urticae and $A$. exsertus.

\section{MATERIALS AND METHODS}

1. Mite sources:

1.1 Tetranychus urticae Koch:

Stock colony of Tetranychus urticae was originated from infested leaves of castor plants, Ricinus communis. The colony had been reared on bean plants, Phaseolus vulgaris cultivated in pots at $22 \pm 2^{\circ} \mathrm{C}$, and $60 \pm 5 \mathrm{RH} \%$ under natural daylight in the experimental greenhouse.

\subsection{Agistemus exsertus Gonzalez:}

The predatory stigmaid mite, Agistemus exsertus adult females were collected from leaves of broad bean plants, Vicia faba cultivated in acarology greenhouse, Faculty of Agriculture, Menoufia University.

\section{Essential oils used:}

Three aqueous concentrations $(0.5$, 1.0, 2.5 and $10 \%$ ), of each oil: Garlic, Thyme, Menthol, Jojoba and Camphor were conducted with four replicates for each. Tested materials were sprayed by a glass atomizer.

Table (1): English name, scientific name, Family name and Arabic name of five essential oils used.

\begin{tabular}{|c|c|c|c|}
\hline $\begin{array}{c}\text { English } \\
\text { name }\end{array}$ & $\begin{array}{c}\text { Scientific } \\
\text { name }\end{array}$ & Family name & $\begin{array}{c}\text { Arabic } \\
\text { name }\end{array}$ \\
\hline Garlic & Allium sativum & Alliaceae & الثوم \\
\hline Thyme & Thymus vulgaris & Lamiaceae & 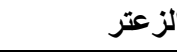 \\
\hline Menthol & Mentha piperita & Lamiaceae & ل لنغناع البلدى \\
\hline Jojoba & Simmondsia Chinensis & Simmondsiaceae & 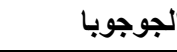 \\
\hline Camphor & Eucalyptus globulus & Myrtaceae & الكافور \\
\hline
\end{tabular}


3. Toxicity effect of five oils against Tetranychus urticae and Agistemus exsertus:

Five essential oils of Garlic, Thyme, Menthol, Jojoba and Camphor were used at concentrations of $0.5,1.0,2.0,5.0$ and $10.0 \%$ for each oil treatment. Four leaf discs $(2 \mathrm{~cm}$ diameter) of fresh leaves of broad bean plants, Vicia faba were placed upside down on wet cotton pad in Petri dish (9 cm in diameter) which represents as four replicates for each concentration of tested oil. Ten adult females of $T$. urticae were transferred to each leaf disc before spraying essential oil solution. Tested oils were sprayed by a glass atomizer. The treated adult females were kept under laboratory conditions $\left(25 \pm 2^{\circ} \mathrm{C}\right.$ and $60 \pm 5 \%$ R.H.).

The same mentioned technique was used with the predatory mite Agistemus exsertus. Ten movable stages of $A$. exsertus were transferred to each disc, individuals of $T$. urticae were added as prey. Predatory mite was maintained under laboratory conditions $\left(25 \pm 2^{\circ} \mathrm{C}\right.$ and $60 \pm 5 \%$ R.H.). Mortality percentages were calculated for $T$. urticae and $A$. exsertus after $24 \mathrm{hrs}$ of spraying for a week and estimated by Abbot's formula (1925).

\section{Repellent and attractant activity experiments:}

The repellency and attractancy tests were made according to the method described by Kogan \& Goeden (1970). Leaf disks of green bean plants of $4.0 \mathrm{~cm}$ diameter were used to evaluate the repellent activity of the essential oils. Half of the disk was sprayed with essential oil of three concentrations 0.5 , 1.0 and $2.0 \%$. After drying, the other half of the disk was sprayed with water, which served as control. Four leaf discs of fresh leaves of green bean were placed upside down on wet cotton pad in a Petri dish 9 $\mathrm{cm}$ diameter. Five adult females of mites were put on each disk, each treatment was repeated four times. The repellent activity evaluation was made after 1 and $6 \mathrm{hrs}$, where mites present on each half of the leaf disk were counted. Mites found in the neutral area were considered as repellent or attracted, based on their proximity to the blank or to the treatment. The Repellent Index (RI) of the oils was calculated according to the equation:

$R p=(C-T / C+T) \times 100$ proposed by Pascual - Villalobos and Robledo (1998), Where $C=$ number of mites on control half, $T=$ number of mites on treated half. RI varying from -100 (Total attractancy) to +100 total repellency), with 0 meaning no effect.

\section{RESULTS AND DISCUSSION}

\section{The toxicity effect of essential oils:}

Toxicity effect of five essential oils were experiments against both the phytophagous mite, Tetranychus urticae and the predatory mite, Agistemus exsertus under laboratory conditions.

\subsection{Effect on Tetranychus urticae:}

Data in Table 2 cleared that garlic oil gave the highest percentages of mortality when used at $2 \%$ concentration (81.43\%) as mean mortality where 0.5 and $1 \%$ concentrations recorded 55.71 and $\mathbf{6 2 . 1 4 \%}$ as mean mortality.

After 7 days of spray both 5 and $10 \%$ concentrations recorded 91.42 and $94.29 \%$ respectively, followed by camphor, recorded 27.14, 42.86 and $65.00 \%$ mean mortality at $0.5,1.0$ and $2.0 \%$ concentrations while the highest concentrations $5,10 \%$ recorded 80.0 , $\mathbf{8 2 . 8 6 \%}$ only, as for jojoba oil, it recorded only $32.14 \%$ mean mortality ranged from 6.43 to $79.29 \%$ when concentrations from 0.5 to $10 \%$ used. The same results obtained when thyme used, it recorded $29.29 \%$ mean mortality at $2.0 \%$ concentration, while $0.5,1.0,5.0,10.0 \%$ concentrations recorded $7.86,13.57$, 
58.57 and $85.14 \%$ mean mortality. The lowest effect was obtained when menthol oil was used, only $14.29 \%$ mean mortality obtained at $2.0 \%$ concentration while the highest mortality obtained at $10.0 \%$ concentration ( $77.86 \%$ after 7 days).

\subsection{Effect on Agistemus exsertus:}

Data in Table 3 cleared that both garlic and camphor have high toxic effect when
$5.0 \%$ and $10.0 \%$ concentration used, record $66.43,79.29 \%$ for garlic and 62.14 , $77.14 \%$ for camphor. While thyme gave $60.71 \%$ followed by jojoba (43.57\%) as mean mortality with $10.0 \%$ concentration. The most safety oil on the predatory mite was menthol, without any effect at 0.5 , $1.0,2.0 \%$ concentration and only $14.29 \%$ mean mortality at $10.0 \%$ concentration.

Table 2: Toxicity effect of five essential oils on the phytophagous mite, Tetranychus urticae.

\begin{tabular}{|c|c|c|c|c|c|c|c|c|}
\hline \multirow{3}{*}{$\begin{array}{c}\text { Oil } \\
\text { conc. }\end{array}$} & \multicolumn{7}{|c|}{ Mortality Percentage (\%M) } & \multirow{3}{*}{$\begin{array}{c}\% \\
\text { Mean }\end{array}$} \\
\hline & $1 d$ & $2 d$ & $3 d$ & $4 d$ & $5 d$ & $6 d$ & $7 d$ & \\
\hline & \multicolumn{7}{|c|}{ Menthol } & \\
\hline $0.5 \%$ & 0 & 5 & 5 & 5 & 5 & 5 & 5 & 4.29 \\
\hline $1.0 \%$ & 0 & 5 & 15 & 15 & 15 & 15 & 15 & 11.43 \\
\hline $2.0 \%$ & 0 & 5 & 15 & 20 & 20 & 20 & 20 & 14.29 \\
\hline $5.0 \%$ & 5 & 10 & 25 & 30 & 35 & 35 & 35 & 25.71 \\
\hline \multirow[t]{2}{*}{$10.0 \%$} & 35 & 70 & 70 & 85 & 95 & 95 & 95 & 77.86 \\
\hline & \multicolumn{7}{|c|}{ Garlic } & \\
\hline $0.5 \%$ & 5 & 35 & 50 & 60 & 70 & 80 & 90 & 55.71 \\
\hline $1.0 \%$ & 5 & 45 & 60 & 65 & 70 & 90 & 100 & 62.14 \\
\hline $2.0 \%$ & 20 & 75 & 85 & 90 & 100 & 100 & 100 & 81.43 \\
\hline $5.0 \%$ & 52 & 85 & 100 & 100 & 100 & 100 & 100 & 91.42 \\
\hline \multirow[t]{2}{*}{$10.0 \%$} & 70 & 90 & 100 & 100 & 100 & 100 & 100 & 94.29 \\
\hline & \multicolumn{7}{|c|}{ Camphor } & \\
\hline $0.5 \%$ & 5 & 10 & 20 & 30 & 35 & 45 & 45 & 27.14 \\
\hline $1.0 \%$ & 15 & 30 & 35 & 45 & 50 & 60 & 65 & 42.86 \\
\hline $2.0 \%$ & 25 & 40 & 55 & 65 & 75 & 95 & 100 & 65.00 \\
\hline $5.0 \%$ & 55 & 55 & 65 & 85 & 100 & 100 & 100 & 80.00 \\
\hline \multirow[t]{2}{*}{$10.0 \%$} & 55 & 65 & 70 & 90 & 100 & 100 & 100 & 82.86 \\
\hline & \multicolumn{7}{|c|}{ Jojoba } & \\
\hline $0.5 \%$ & 0 & 0 & 5 & 10 & 10 & 10 & 10 & 6.43 \\
\hline $1.0 \%$ & 0 & 5 & 10 & 15 & 20 & 20 & 20 & 12.86 \\
\hline $2.0 \%$ & 15 & 25 & 35 & 35 & 35 & 35 & 35 & 32.14 \\
\hline $5.0 \%$ & 25 & 45 & 45 & 50 & 50 & 50 & 55 & 45.71 \\
\hline \multirow[t]{2}{*}{$10.0 \%$} & 40 & 65 & 80 & 85 & 95 & 95 & 95 & 79.29 \\
\hline & \multicolumn{7}{|c|}{ Thyme } & \\
\hline $0.5 \%$ & 0 & 0 & 5 & 10 & 10 & 15 & 15 & 7.86 \\
\hline $1.0 \%$ & 0 & 5 & 10 & 15 & 20 & 20 & 25 & 13.57 \\
\hline $2.0 \%$ & 10 & 25 & 25 & 30 & 35 & 40 & 40 & 29.29 \\
\hline $5.0 \%$ & 25 & 50 & 50 & 65 & 70 & 75 & 75 & 58.57 \\
\hline $10.0 \%$ & 45 & 65 & 85 & 95 & 95 & 95 & 95 & 85.14 \\
\hline
\end{tabular}




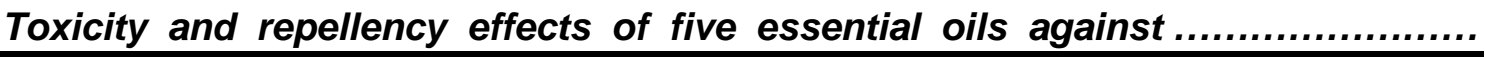

Table 3: Toxicity effect of five essential oils on the predatory mite, Agistemus exsertus.

\begin{tabular}{|c|c|c|c|c|c|c|c|c|}
\hline \multirow{3}{*}{$\begin{array}{l}\text { Oil } \\
\text { conc. }\end{array}$} & \multicolumn{7}{|c|}{ Mortality Percentage (\%M) } & \multirow{3}{*}{$\begin{array}{c}\% \\
\text { Mean }\end{array}$} \\
\hline & $1 d$ & $2 d$ & 3d & $4 d$ & $5 d$ & $6 d$ & $7 d$ & \\
\hline & \multicolumn{7}{|c|}{ Menthol } & \\
\hline $0.5 \%$ & 0 & 0 & 0 & 0 & 0 & 0 & 0 & 0 \\
\hline $1.0 \%$ & 0 & 0 & 0 & 0 & 0 & 0 & 0 & 0 \\
\hline $2.0 \%$ & 0 & 0 & 0 & 0 & 0 & 0 & 0 & 0 \\
\hline $5.0 \%$ & 0 & 0 & 5 & 10 & 10 & 10 & 10 & 6.43 \\
\hline \multirow[t]{2}{*}{$10.0 \%$} & 10 & 10 & 10 & 10 & 20 & 20 & 20 & 14.29 \\
\hline & \multicolumn{7}{|c|}{ Garlic } & \\
\hline $0.5 \%$ & 0 & 0 & 5 & 10 & 15 & 15 & 15 & 8.57 \\
\hline $1.0 \%$ & 0 & 5 & 10 & 15 & 20 & 25 & 25 & 14.29 \\
\hline $2.0 \%$ & 0 & 15 & 25 & 25 & 35 & 40 & 40 & 25.71 \\
\hline $5.0 \%$ & 60 & 60 & 60 & 60 & 75 & 75 & 75 & 66.43 \\
\hline \multirow[t]{2}{*}{$10.0 \%$} & 70 & 70 & 75 & 85 & 85 & 85 & 85 & 79.29 \\
\hline & \multicolumn{7}{|c|}{ Camphor } & \\
\hline $0.5 \%$ & 0 & 5 & 5 & 5 & 10 & 10 & 15 & 7.14 \\
\hline $1.0 \%$ & 5 & 10 & 15 & 15 & 25 & 25 & 25 & 17.14 \\
\hline $2.0 \%$ & 10 & 15 & 25 & 30 & 35 & 35 & 40 & 27.14 \\
\hline $5.0 \%$ & 50 & 50 & 65 & 65 & 65 & 70 & 70 & 62.14 \\
\hline \multirow[t]{2}{*}{$10.0 \%$} & 60 & 60 & 20 & 70 & 90 & 95 & 95 & 77.14 \\
\hline & \multicolumn{7}{|c|}{ Jojoba } & \\
\hline $0.5 \%$ & 0 & 0 & 0 & 0 & 0 & 0 & 0 & 0 \\
\hline $1.0 \%$ & 0 & 0 & 5 & 5 & 5 & 5 & 5 & 3.57 \\
\hline $2.0 \%$ & 15 & 15 & 15 & 15 & 25 & 25 & 30 & 20.00 \\
\hline $5.0 \%$ & 20 & 20 & 20 & 30 & 30 & 30 & 30 & 25.71 \\
\hline \multirow[t]{2}{*}{$10.0 \%$} & 25 & 25 & 25 & 40 & 60 & 60 & 65 & 43.57 \\
\hline & \multicolumn{7}{|c|}{ Thyme } & \\
\hline $0.5 \%$ & 0 & 0 & 0 & 0 & 0 & 0 & 0 & 0 \\
\hline $1.0 \%$ & 0 & 0 & 5 & 5 & 5 & 5 & 5 & 3.57 \\
\hline $2.0 \%$ & 5 & 5 & 10 & 10 & 10 & 10 & 15 & 9.29 \\
\hline $5.0 \%$ & 25 & 25 & 30 & 35 & 45 & 45 & 45 & 35.71 \\
\hline $10.0 \%$ & 30 & 40 & 55 & 70 & 70 & 80 & 80 & 60.71 \\
\hline
\end{tabular}

2. The repellency and attractancy effect:

Laboratory experiment was conducted to evaluate the repellency or attractancy effect of five essential oils with $0.5,1.0$, and $2.0 \%$ concentration

\subsection{On Tetranychus urticae:}

Data in Table 4 showed that menthol and camphor have high repellency effect after one and six hours, menthol gave
$100 \%$ repellency at $1.0 \%$ and $2.0 \%$ concentration after one hour and 90, $100 \%$ after six hours. Also camphor recorded $100 \%$ repellency for the same concentrations after one and six hours followed by jojoba, where repellency percentage was $75 \%$ and $95 \%$ after one and six hours at $\mathbf{2 . 0 \%}$ concentration, while garlic have good repellency after one hour $55,60,75 \%$ but it decreased to $40,30,20 \%$ after six hours when $0.5,1.0$ 
and $2.0 \%$ concentration used. Thyme have the lowest repellency effect recorded the second class of repellency (21:40\%) after one hour and the first class of repellency after six hours at $\mathbf{1 . 0}$ and $2.0 \%$ concentrations while $0.5 \%$ gave little attractancy (-5\%).

\subsection{On Agistemus exsertus:}

Data in Table 5 showed that the camphor oil gave the highest repellency oil $0.5,2.0 \%$ concentration gave $50,60 \%$ repellency after one and six hours followed by menthol where repellency were 30 and $25 \%$ after one and six hours for $2.0 \%$ concentration. Jojoba haven't any effect for $0.5 \%$ concentration after one hour and attractive effect after six hours $(-5 \%)$ while both $1 \%$ have first class of repellency $10.0 \%$ after one and six hours, $2.0 \%$ concentration haven't any effect after six hours. Garlic have slight repellency effect after one hour while after six hours gave slight attractive $-5,-10 \%$ for 0.5 and $1.0 \%$ concentrations while $2.0 \%$ haven't repellency or attractancy effect. Thyme as general have attractancy effect from the first class for the three concentrations after six hours.

Table 4: the repellency and attractancy effect of some oils on Tetranychus urticae.

\begin{tabular}{|c|c|c|c|c|c|c|c|c|}
\hline \multirow[b]{2}{*}{$\begin{array}{l}\text { Plant } \\
\text { oils }\end{array}$} & \multicolumn{4}{|c|}{ One hour } & \multicolumn{4}{|c|}{ Six hours } \\
\hline & $\mathbf{T}$ & C & RP\% & Class & $\mathbf{T}$ & C & RP\% & Class \\
\hline & \multicolumn{8}{|c|}{ Menthol } \\
\hline $0.5 \%$ & 1 & 39 & 95 & $\mathrm{Vr}$ & 4 & 36 & 80 & $\mathrm{IVr}$ \\
\hline $1.0 \%$ & 0 & 40 & 100 & $\mathrm{Vr}$ & 2 & 38 & 90 & $\mathrm{Vr}$ \\
\hline \multirow[t]{2}{*}{$2.0 \%$} & 0 & 40 & 100 & $\mathrm{Vr}$ & 0 & 40 & 100 & $\mathrm{Vr}$ \\
\hline & \multicolumn{8}{|c|}{ Garlic } \\
\hline $0.5 \%$ & 9 & 31 & 55 & IIIr & 12 & 28 & 40 & IIr \\
\hline $1.0 \%$ & 8 & 32 & 60 & IIIr & 14 & 26 & 30 & IIr \\
\hline \multirow[t]{2}{*}{$2.0 \%$} & 5 & 35 & 75 & IVr & 16 & 24 & 20 & Ir \\
\hline & \multicolumn{8}{|c|}{ Camphor } \\
\hline $0.5 \%$ & 2 & 38 & 90 & $\mathrm{Vr}$ & 2 & 38 & 90 & $\mathrm{Vr}$ \\
\hline $1.0 \%$ & 0 & 40 & 100 & $\mathrm{Vr}$ & 0 & 40 & 100 & $\mathrm{Vr}$ \\
\hline \multirow[t]{2}{*}{$2.0 \%$} & 0 & 40 & 100 & $\mathrm{Vr}$ & 0 & 40 & 100 & $\mathrm{Vr}$ \\
\hline & \multicolumn{8}{|c|}{ Jojoba } \\
\hline $0.5 \%$ & 10 & 30 & 50 & IIIr & 7 & 33 & 65 & IIIr \\
\hline $1.0 \%$ & 8 & 32 & 60 & IIIr & 5 & 35 & 75 & $\mathrm{IVr}$ \\
\hline \multirow[t]{2}{*}{$2.0 \%$} & 5 & 35 & 75 & $\mathrm{IVr}$ & 1 & 39 & 95 & $\mathrm{Vr}$ \\
\hline & \multicolumn{8}{|c|}{ Thyme } \\
\hline $0.5 \%$ & 15 & 25 & 25 & IIr & 21 & 19 & -5 & la \\
\hline $1.0 \%$ & 12 & 28 & 40 & IIr & 18 & 22 & 10 & Ir \\
\hline $2.0 \%$ & 12 & 28 & 40 & IIr & 18 & 22 & 10 & 0 \\
\hline
\end{tabular}




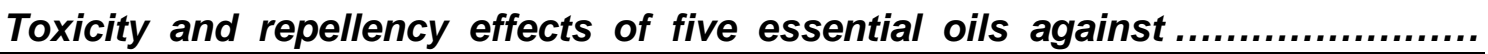

Table 5: the repellency and attractancy effect of some oils on Agistemus exsertus.

\begin{tabular}{|c|c|c|c|c|c|c|c|c|}
\hline & \multicolumn{4}{|c|}{ One hour } & \multicolumn{4}{|c|}{ Six hours } \\
\hline Plant oils & $T$ & C & RP\% & Class & $T$ & C & RP\% & Class \\
\hline & \multicolumn{8}{|c|}{ Menthol } \\
\hline $0.5 \%$ & 16 & 24 & 20 & Ir & 18 & 22 & 10 & Ir \\
\hline $1.0 \%$ & 14 & 26 & 30 & IIr & 15 & 25 & 15 & IIr \\
\hline \multirow[t]{2}{*}{$2.0 \%$} & 14 & 26 & 30 & IIr & 17 & 23 & 25 & Ir \\
\hline & \multicolumn{8}{|c|}{ Garlic } \\
\hline $0.5 \%$ & 15 & 25 & 25 & IIr & 21 & 19 & -5 & la \\
\hline $1.0 \%$ & 18 & 22 & 10 & Ir & 22 & 18 & -10 & la \\
\hline \multirow[t]{2}{*}{$2.0 \%$} & 14 & 26 & 30 & IIr & 20 & 20 & 0 & 0 \\
\hline & \multicolumn{8}{|c|}{ Camphor } \\
\hline $0.5 \%$ & 10 & 30 & 50 & Ir & 8 & 32 & 60 & IIr \\
\hline $1.0 \%$ & 12 & 28 & 40 & IIr & 10 & 30 & 50 & IIr \\
\hline \multirow[t]{2}{*}{$2.0 \%$} & 17 & 23 & 15 & IIIr & 14 & 26 & 30 & IIIr \\
\hline & \multicolumn{8}{|c|}{ Jojoba } \\
\hline $0.5 \%$ & 20 & 20 & 0 & 0 & 21 & 19 & -5 & la \\
\hline $1.0 \%$ & 18 & 22 & 10 & Ir & 18 & 22 & 10 & Ir \\
\hline \multirow[t]{2}{*}{$2.0 \%$} & 19 & 21 & 5 & Ir & 20 & 20 & 0 & 0 \\
\hline & \multicolumn{8}{|c|}{ Thyme } \\
\hline $0.5 \%$ & 21 & 19 & -5 & la & 22 & 18 & -10 & la \\
\hline $1.0 \%$ & 20 & 20 & 0 & 0 & 21 & 19 & -5 & la \\
\hline $2.0 \%$ & 21 & 19 & 5 & Ir & 22 & 18 & -10 & la \\
\hline
\end{tabular}

Discussion of results revealed that both garlic and camphor are sufficient oils to control of Tetranychus urticae at $10.0 \%$ concentration and camphor appear as good repellency oil with less repellency effect and toxicity on Agistemus exsertus. Also menthol have high repellency effect on $T$. urticae and good toxicity effect on $T$. urticae with safe use on $A$. exsertus and thyme have sufficient toxicity effect on $T$. urticae. The obtained results are in harmony with those conducted by Sertkaya, et al., 2010; Abd El-Moneim, 2012; Motazedian, et al., 2012; who studied the toxicity and repellency effects of three essential oils against Tetranychus urticae.

\section{REFERENCES}

Abbott, W.S. (1925). A method of computing the effectiveness of an insecticide. J. Econ. Ent., 18, 265-267.
Afify, A.M., Fatma S. Ali and A.F. Turky (2012). Control of Tetranychus urticae Koch by extracts of three essential oils of chamomile, marjoram and Eucalyptus. Asian Pac. J. Trop. Biomed. 2(1): 24-30.

Cosimi, S., E. Rossi, P. L. Cioni and A. Canale (2009). Bioactivity and qualitative analysis of some essential oils from Mediterranean Plants against stored-product Pests: evaluation of repellency against Sitophilus zeamais Motschulsky, Cryptolestes ferrugineus (Stephens) and Tenebrio molitor (L.). J. Stored Prod. Res., 45: 125-132.

EL-Badry, E. A., M. R. Abou-EL-Ghar, S. M. Hassan and S. A. Kilany (1969). Agistemus exsertus as a predator of two tetranychid mites. -Ann. Ent. Soc. Amer. 62 : 660-661.

EL-Bagoury, M. E., S.M. Hafez and S. A. Fahmy (1989). Biology of Agistemus 
exsertus as affected by feeding on two tetranychid mite species. Annals Agric. Sci., Fac. Agric., Ain Shams Univ., Cairo. Egypt 3: 449-458.

Gomaa, E. A. (1975). The incidence of the raphignathoid mites in Egypt. Ph.D. Thesis, Fac. Agrc., Cairo Univ., 187pp.

Hafez, S. M., A. H. Rasmy and S. A. ELSawi (1983). Influence of prey species and stages on predatory efficiency and development of the stigmaeid mite Agistemus exsertus. Acarologia 24: 281-283.

Hoyt, S. C. (1969). Population studies of five mite species on apple trees in Washington. Proc. 2nd Intern. Congr. Acarology, 117-133.

Isman, M. B. (2006). Botanical Insecticides, Deterrents, and Repellents in Modern Agriculture and an Increasingly Regulated World. Ann. Rev. Entomol., 51: 45-66.

Jeppson, L. R., H. H. Keifer and T. W. Baker (1975). Mites Injurious to Economic Plants. University of California Press, Berkeley, CA, PP. 370-376.

Johnson, W. T. and H. H. Lyon (1991). Insects That Feed on Trees and Shrubs. $2^{\text {nd }}$ Edition, Comstock Publishing/Cornell University Press, Ithaca, NY, PP. 468-470.

Kogan, M. and R. D. Goeden (1970). The host-plant range of Lema trilineata daturaphila (Coleoptera:

Chrysomelidae). Ann. Entomol. Soc. Am., 63: 1175-1180.

Mossi, A.J., C.A. Zanella, G. Kubiak, L.A. Lerin, R.L. Casian and F.S. Frandoloso (2013). Essential oil of Ocotea odorifera: An alternative against Sitophilus zeamais. Renewable Agriculture and Food Systems29:161166.doi:http://dx.doi.org/10.1017/ 1742170513000045.

Motazedian, N., S. Ravan and A.R. Bandani (2012). Toxicity and repellency effects of three essential oils against Tetranychus urticae Koch
(Acari: Tetranychidae). Journal of Agricultural Science and Technology 14:275-284.

Oomen, P. A. (1982). Studies on population dynamics of the scarlet mite, Brevipalpus phoenicis, a pest of tea in Indonesia.-Med. Landbouww. Wageningen 82, $88 \mathrm{p}$.

Pascual-Villalobos, M. J. and A. Robledo (1998). Anti-insect Activity of Plant Extracts from the Wild Flora in Southern Spain. Biochem. Syst. Ecol., 27: 1-10.

Santos, M. A. (1976). Evaluation of Zetzellia mali as a predator of Panonychus ulmi and Aculus schlechtendali. Environ. Entomol. 5: 187-191.

Sertkaya, E., K. Kaya. and S. Soylu (2010). Acaricidal activities of the essential oils from several medicinal plants against the carmine spider mite (Tetranychus cinnabarinus Boisd) (Acarina: Tetranychidae). Industrial Crops Products, 31 (1): 107-112.

Solimon, Z.R., K.K. Shehata and E. A. Gomaa (1976). on the food range and economic importance of the predatory mite, Agistemus exsertus Gonzalez (Acari: Prostigmata). - Anz. fiér. SchäPflanz., Umwelt. 49: 87-90.

Yue, B. and C. Childers (1994). Effects of temperature on life table parameters of Agistemus exsertus Gonzalez (Acari: Stigmaeidae) and its attack rate on Panonychus citri eggs. - Int. J. Acarol. 20: 109-113.

Zaher, M. A., A.M. Afify and E. A. Gomaa (1971). Survey and biology of Agistemus exsertus Gonzalz in U. A. $R$., with description of the immature stages. Z. ang. Ent. 67: 272-279.

Zhang, Q.H., F. Schylter, A. Battisti, G. Birgersson and P. Ander-son (2003). Electrophysiological responses of Thaumetopoea pityocampa females to host volatiles: Implications for host selection of active and inactive terpenes. J. Pest. Sci. 76:103-107. 
التأثير السام والطارد لخمس من الزيوت الأساسية ضد كلا من أكاروس العنكبوت الأحمر Agistemus exsertus والمفترس الأكاروسى من الربوس

\author{
ايمان حسنى محمد ولاش النان \\ معهز بحوث وقاية النباتات - الدقى - الجيزة - مصر
}

الملخص العربى

اجريت دراسه بمعمل ابحاث كلية الزراعة جامعة المنوفية بهدف دراسه التأثير السام والتأثير الجاذب والطارد لخمس زيوت نباتيه هى: (الثوم - الزعتر - النعناع - الجوجويا - الكافور) ضد كلا من اكاروس العنكبوت الاحمر Tetranychus urticae

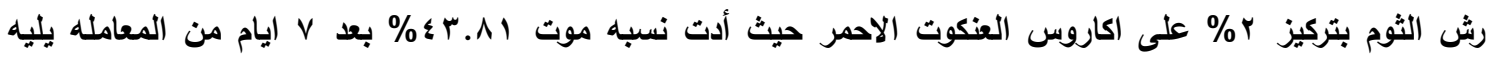

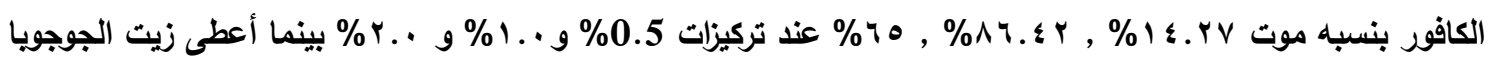

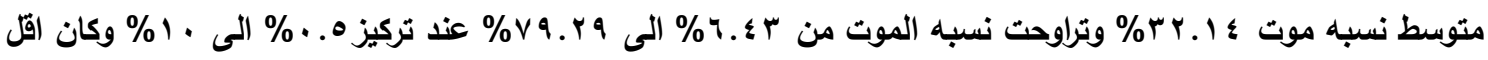

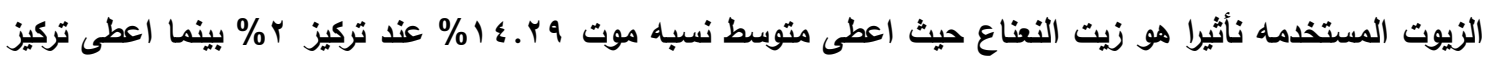

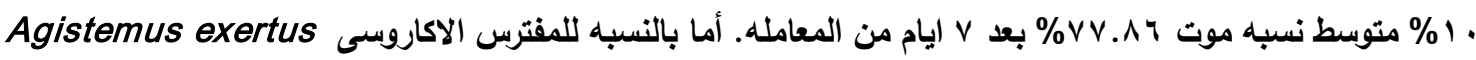

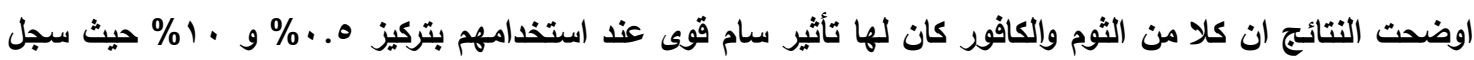

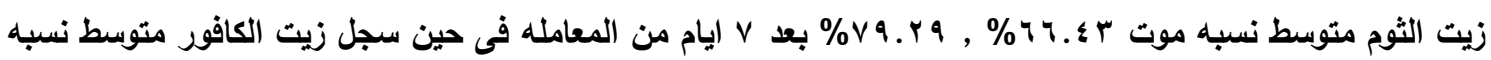

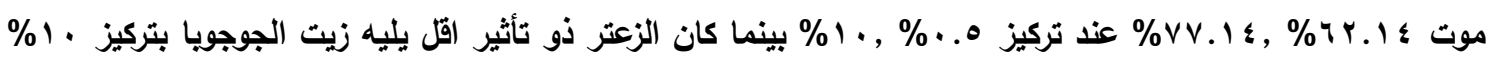

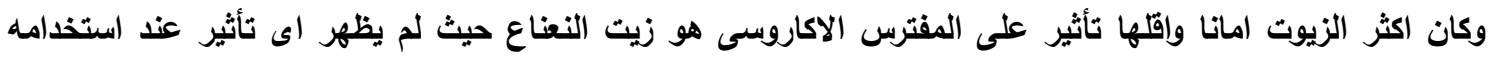

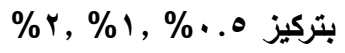

كما اظهرت الدراسه ان كلا من زيت النعناع والكافور كان له تأثير طارد وقوى بعد ساعه و ه ساعات من المعامله

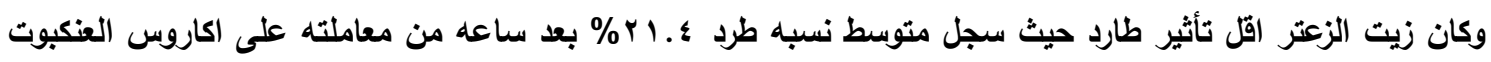

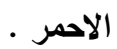

كما اوضحت النتائج ان زيت الكافور كان ذو تأثير طارد قوى عند معامله المفترس الاكاروسى بتركيز ؟\% من النتائج

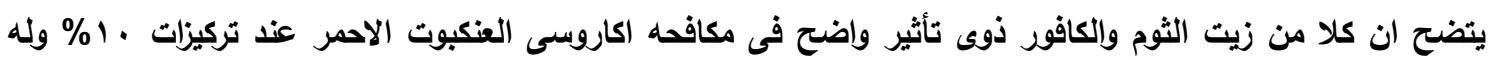

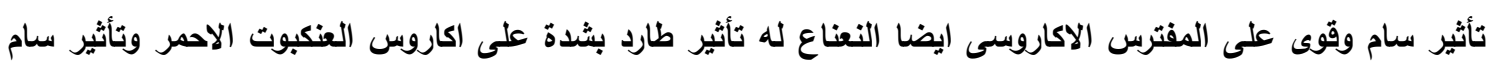

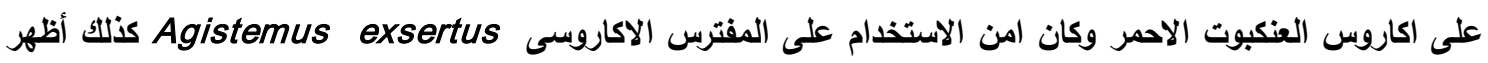
زيت الزعتر تأثير سام واضح على Tetranychus urticae.

أسماء السادة المحكمين

كلية الزراعة - جامعة القاهرة

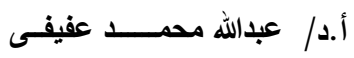

كلية الزراعة - جامعة المنوفية

أ.د/ صفاء مصطفى أبو طاقـة 
